Haapanen, L., L. Kääntä \& L. Lehti (toim.) 2018. Diskurssintutkimuksen menetelmistä. On the methods in discourse studies. AFinLA-e. Soveltavan kielitieteen tutkimuksia 2018/n:o 11. 4-19.

Lotta Lehti ${ }^{1,2}$, Lauri Haapanen ${ }^{3}$ \& Liisa Kääntä ${ }^{4}$

${ }^{1}$ Helsingin yliopisto, ${ }^{2}$ Turun yliopisto, ${ }^{3}$ Jyväskylän yliopisto, ${ }^{4}$ Vaasan yliopisto

\title{
Diskurssintutkimus - monitieteinen ja monimenetelmäinen ala
}

There is a growing interest towards metatheoretical examination of linguistic research. This special issue contributes to this examination from the perspective of discourse studies. The issue consists of seven articles which present methods in different areas of discourse studies. The aim of this introductory article is firstly to define the notions of discourse and method. Secondly, through the presentation of the articles of the issue, we present a variety of methods pertaining to different stages of research. In particular, methods of data collection and classification, as well as of data analysis, are presented. We conclude the article with some remarks on the future avenues of the methodology of discourse studies.

Keywords: discourse studies, research design, method, data, analysis Asiasanat: diskurssintutkimus, tutkimusasetelma, menetelmä, aineisto, analyysi 


\section{Johdanto ${ }^{1}$}

Viime vuosina suomalaisessa kielentutkimuksen kentässä on yleistynyt tutkimussuuntien ja tieteellisten lähestymistapojen itsereflektoiva tarkastelu. Tämä tarkoittaa, että kielentutkijat eivät yksinomaan käytä menetelmiä tutkimuksissaan tai esittele menetelmiä tutkimuksen välineinä vaan myös ottavat menetelmät tutkimuksen kohteeksi ja tarkastelevat niitä metatasolla. Tästä kertovat esimerkiksi menetelmiä käsittelevät teokset (Itkonen \& Pajunen 2010; Kolehmainen ym. 2013; Konstenius 2014) sekä valmisteilla oleva käsikirja (Luodonpää-Manni ym. tulossa), jossa esitellään laaja kirjo kielentutkimuksen eri osa-alueilla käytettyjä menetelmiä. Käsillä oleva teemanumero pyrkii omalta osaltaan edistämään kielentutkimuksen menetelmien ymmärrystä, kehittelyä, soveltamista ja arviointia.

Diskurssintutkimus on laajasti nähtynä tutkimussuuntaus, jota käytetään eri tieteenaloilla ja johon sisältyy erilaisia menetelmiä (mm. Jokinen ym. 2016; Angermuller ym. 2014; Pynnönen 2013; Alba-Juez 2009; Schiffrin ym. 2003). Näin tulkittuna diskurssintutkimus on teoreettis-menetelmällinen viitekehys, jonka puitteissa tehdään tutkimusta kielenkäytön ja yhteiskunnan suhteesta ja jossa kaikkia teoreettisia ja menetelmällisiä valintoja ohjaa ajatus tutkimuskohteesta diskursiivisesti rakentuvina merkityksinä. Näiden merkitysten perimmäisen luonteen kuvaamiseen ja selittämiseen löytyy useita teorioita (esim. sosiokonstruktionismi tai organisaatioviestinnässä sense making -teoria) ja useita menetelmiä (esim. lingvistinen tekstianalyysi, kriittinen diskurssianalyysi, keskustelunanalyysi, retorinen analyysi) (diskurssintutkimuksen merkityslähtöisyydestä esim. Wetherell, Taylor \& Yates 2001). Merkittävää on, että näitä teorioita ja menetelmiä voidaan käyttää muissakin tutkimussuuntauksissa tai yhdistää niihin, mutta silloin niiden käyttötapa eroaa diskurssintutkimuksen tavoista eikä kohdistu nimenomaan diskursiivisten merkitysten analysoimiseen (ks. Jokinen 2016). Tutkija voi siis tehdä esimerkiksi sosiokonstruktionismiin pohjautuvaa vertailevaa lingvististä tekstintutkimusta ilman, että silloin on automaattisesti kyse diskurssintutkimuksesta.

Diskurssintutkimuksesta kumpuavia menetelmiä hyödynnetään kielentutkimuksen lisäksi esimerkiksi yhteiskuntatieteissä, kauppatieteissä ja kasvatustieteissä. Laaja-alaisuudestaan huolimatta diskurssintutkimus-kattotermin alle sijoittuvat menetelmät jakavat joitain lähtökohtia ja käsityksiä; diskurssintutkimus on merkityksiin pohjautuva tutkimussuuntaus, jossa kielenkäyttö nähdään sosiaalisena toimintana ja diskurssit tilannekohtaisina (vrt. Jokinen ym. 2016) - joskin viimeisestä on eriäviä näkemyksiä diskurssintutkimuksen eri koulukunnissa (ks. esim. Wodak \& Meyer

1 Tämän teemanumeron taustalla on AFinLAn diskurssintutkimuksen teemaryhmä ja erityisesti teemaryhmän järjestämä työpaja "Diskurssintutkimuksen menetelmiä nyt ja tulevaisuudessa", joka pidettiin Kielitieteen päivillä 2017 Jyväskylässä. Osa teemanumeron artikkeleista perustuu työpajassa pidettyihin esitelmiin. 
2001). Yksi vahva yhteinen tekijä on myös se, että useimmat diskurssintutkimuksen menetelmät perustuvat laadulliseen tutkimusotteeseen.

Diskurssintutkimus-kattotermistä puhuttaessa on oleellista ymmärtää, että se ei ole synonyymi diskurssianalyysille, vaan diskurssianalyysi on yksi menetelmällinen lähestymistapa muiden mahdollisten joukossa². Esimerkiksi kauppatieteissä usein käytetylle diskursiiviselle sisällönanalyysille on tyypillistä merkitysten analyysi eli sisällön teemoittelu, kun taas soveltavassa kielitieteessä käytetylle kriittiselle diskurssianalyysille on keskeistä kielenkäytön analyysi niin merkityksen kuin muodonkin näkökulmasta. Kriittisessä diskurssianalyysissä teksteistä analysoidaan valtasuhteita ilmaisevien sanatason merkitysten lisäksi kielellisiä muotoja, joissa valtarakenteet ilmenevät ja jotka edelleen rakentavat niitä. Diskurssintutkimus-kattotermin alla kukin tutkija voi siis tehdä valintoja sen mukaisesti, minkälaiseen kielenkäyttöön ja yhteiskunnan sekä sosiaalisen todellisuuden suhteeseen hänen kiinnostuksensa kohdistuu, minkälaisista aineistoista tätä suhdetta analysoidaan ja minkälaisten lähtökohtien vallitessa: painottaako tutkija esimerkiksi tutkimuskohteensa merkitysten tarkastelua puhetapoina, vuorovaikutustilanteina, tulkintarepertuaareina, teemoina, merkityssysteemeinä, ideologisesti värittyneinä puheakteina, kategorioina tai sosiokulttuurisina käytänteinä (mm. Jokinen ym. 2016; ks. myös luku 2). Tutkimuksen kohde määrittää tutkimuksen menetelmän tai menetelmien valintaa: esimerkiksi kategorioihin painottuva tutkimus nojaa menetelmältään tyypillisesti diskursiiviseen psykologiaan eikä esimerkiksi kriittiseen diskurssianalyysiin, mutta diskursiiviseen psykologiaan voidaan tällaisessa tutkimuksessa yhdistää luontevasti etnometodologista keskustelunanalyysia (ks. Stevanovic \& Weiste tässä teemanumerossa).

Diskurssintutkimuksen tutkimuskenttä on viime aikoina laajentunut huomioimaan kirjoitetun ja puhutun kielen lisäksi visuaalisen ja multimodaalisen viestinnän piirteitä (Blommaert 2005; Gunther \& van Leeuwen 2001; ledema 2003; Machin 2013). Teknologian kehityksen myötä diskurssintutkimuksessa otetaan yhä enemmän käyttöön myös esimerkiksi laskennallisia menetelmiä (ks. Jantunen tässä teemanumerossa) sekä monipuolisempia ja prosessimaisempia aineistojen keräämisja tallentamistapoja (ks. esim. Grésillon \& Perrin 2014; Krzyżanowski 2011). Monien tutkimusten kohdalla aineistojen keruu on työlästä ja aikaavievää, joten aineistojen jatkokäyttöön on alettu kiinnittää entistä enemmän huomiota. Tämä yhdessä tutkimuslupien ja tutkimuseettisten näkökulmien tiukentumisen kanssa vaatii hyvää suunnittelua jo ennen varsinaisen aineiston keruun ja analyysin aloittamista.

2 Diskurssintutkimuksen ja diskurssianalyysin erottaminen toisistaan on ollut vähäistä alan kirjallisuudessa, ja niitä käytetäänkin usein synonyymeinä toisistaan, usein myös kritiikittömästi. Olemme kuitenkin kokeneet artikkeleiden kirjon pohjalta tehdä tässä teemanumerossa eroa näiden kahden välille. Teemanumeromme artikkeleista yksikään ei edusta puhdasta diskurssianalyysia, mutta ne jakavat kuitenkin muita diskurssintutkimukselle keskeisiä lähtökohtia ja diskurssin eri merkitykset ovat niissä läsnä. 
Diskurssintutkimuksessa käytetyt tutkimusmenetelmät ovat lähtökohtia, kehyksiä, joita tutkija ei voi suoraan "ottaa hyllystä" ja soveltaa aineistoonsa, vaikka joissain tilanteissa, esimerkiksi keskustelunanalyysin (esim. Stevanovic \& Lindholm 2016) ja systeemis-funktionaalisen suhtautumisen teorian kohdalla (Martin \& White 2005), liitto teorian ja menetelmän välillä on hyvin likeinen, pitkälle kehitelty ja vakioitu. Yksittäisen tutkimuksen kysymyksiin vastatessaan tutkija voi operationalisoida teoreettisia käsitteitä metodiksi, kuten tarkastelemalla legitimaatiota sille ominaisten diskursiivisten merkitysten avulla (Porttikivi 2016; Reyes 2011). Toisaalta tutkija voi hyödyntää tarkkoja menetelmällisiä luokitteluja sisältäviä teorioita, kuten edellä mainittuja keskustelunanalyysia tai suhtautumisen teoriaa arvioivista ja arvottavista merkityksistä kielenkäytössä (esim. Mikkonen 2010). Kolmas vaihtoehto on vastata tutkimustehtävän tarpeisiin yhdistelemällä ja kehittelemällä uudenlainen menetelmien synteesi (esim. progression analysis, ks. Perrin 2003; kvalitatiivisen ja kvantitatiivisen tutkimuksen yhdistämisestä, ks. Niglas 2004).

Moni diskurssintutkija on ymmällään menetelmien kirjon edessä. Siinä missä diskurssintutkimus ei ole koskaan ollut erityisen selvärajainen tutkimusparadigma, ovat sen rajat nyt entisestään liudentuneet suhteessa muihin tutkimusparadigmoihin ja niiden lähestymistapoihin. Tämän teemanumeron tarkoituksena on tarjota näkökulmia siihen, millä tavoin tutkimuksellisiin ja menetelmällisiin haasteisiin voidaan reagoida. Teemanumeromme seitsemän artikkelin kautta on esillä erilaisia tutkimusasetelmia, joissa diskurssintutkimusta ja siihen liittyviä menetelmiä kehitetään monin tavoin. Artikkeleissa osoitetaan, miten tutkimusasetelmaa rakentavilla valinnoilla kukin tutkija luo omanlaisensa käsityksen diskurssintutkimuksesta, tutkimusparadigman peruskäsityksistä, diskurssin merkityksestä, käyttökelpoisesta menetelmästä, monimenetelmäisyydestä ja teknologisen kehityksen vaikutuksesta tutkimuksen tekemiseen. Ennen kuin esittelemme artikkelit tästä näkökulmasta, kartoitamme diskurssin käsitettä ja kuvaamme lyhyesti, millaisia suuntauksia diskurssintutkimuksen alaan voi kuulua.

\section{Mitä diskurssi tarkoittaa ja miten sitä voi tutkia?}

Sana diskurssi juontaa juurensa keskiajan latinaan, jossa se tarkoitti kiertämistä tai ympäri juoksemista (Renkema 2004: 48). Diskurssi siis "juoksee" kielenkäyttäjältä toiselle, toistuu tekstistä toiseen. Yksittäinen esiintymä ei luo diskurssia vaan tekstistä toiseen toistuvat piirteet samoin kuin tietylle diskurssille ominaisten piirteiden tiheä esiintyminen yhdessä tekstissä (ks. Virsu 2012: 30). Näin syntyy kielellisiä sosiaalisia käytäntöjä, jotka ovat ominaisia tietyille ihmisryhmille, viestintätilanteille, ideologioille tai vaikkapa yhteiskunnan osa-alueille. Voidaan puhua esimerkiksi uutisdiskurssista, akateemisesta diskurssista tai feministisestä diskurssista. Kriittisen diskurssianalyysin kehittäjä Norman Fairclough (2003: 124) käsittää diskurssin juuri tässä 
merkityksessä kielenkäyttötavaksi, joka heijastaa tiettyä maailmankuvaa ja samalla myös rakentaa sitä edelleen. Jokinen ym. (2016: 34) korostavat sekä diskurssin että sen rinnakkaiskäsitteen tulkintarepertuaarin ${ }^{3}$ konstruktivistista luonnetta ja määrittelevät ne "verrattain eheiksi säännönmukaisten merkityssuhteiden systeemeiksi, jotka rakentuvat sosiaalisissa käytännöissä ja samalla rakentavat sosiaalista todellisuutta". Parker (1992) puolestaan määrittelee diskurssin seitsemän kriteerin avulla: diskurssi 1) realisoituu tekstissä, 2) liittyy reaalimaailman objekteihin, 3) sisältää toimijoita, 4) on yhtenäinen merkityssysteemi, 5) viittaa toisiin diskursseihin, 6) reflektoi omaa puhetapaansa ja 7) on historiallinen.

Eri diskurssien lisäksi keskeinen kielenkäytön luokittelukeino on genre, jota suomeksi usein kutsutaan tekstilajiksi. Genret heijastelevat kunkin viestintätilanteen tavoitteita ja tehtäviä ja ovat viestintätilanteiden malleja, jotka realisoituvat enemmän ja vähemmän prototyyppisissä teksteissä (ks. esim. Miller 1984). Esimerkiksi uutinen, hääkutsu tai työhaastattelu ovat monelle tuttuja genrejä, jotka tunnistetaan vaivatta. Jokainen uutinen, hääkutsu tai työhaastattelu toteutuu kuitenkin hiukan eri tavalla. Tunnistamme käsillä olevan tilanteen tiettyyn genreen kuuluvaksi erityisesti osallistujien roolien ja viestinnän tarkoituksen avulla (mt.). Kuten Pietikäinen ja Mäntynen (2009: 81) toteavat, diskurssin ja genren käsitteillä on sekä yhtäläisyyksiä että eroja. Molemmat ovat kielellisen sosiaalisen toiminnan resursseja ja molemmissa yhdistyy teksti ja laajempi konteksti. Tärkein ero piilee siinä, että "kun diskurssit ovat tapoja rakentaa ja merkityksellistää maailmaa, genret ovat vakiintuneita tapoja rakentaa sosiaalista toimintaa" (Pietikäinen \& Mäntynen 2009: 81). Yhtä genreä edustava teksti voi edustaa monia eri diskursseja: esimerkiksi mielipidekirjoitus-genreen kuuluvat tekstit voivat edustaa ja yhdistellä eri diskursseja. Lisäksi joillain genreillä on oma diskurssinsa (esim. uutisgenre ja uutisdiskurssi) kun taas toiset genret voivat kuulua eri diskursseihin (esim. kokousmuistio voi kuulua vaikkapa akateemiseen tai poliittiseen diskurssiin).

Toisaalta diskurssi voidaan määritellä löyhemmin kielen käytöksi kontekstissa (esim. Brown \&Yule 1983). Myös tämä määritys nojautuu ajatukseen kielenkäyttäjien välisistä yhteyksistä: kielenkäyttö ymmärretään sekä kielellisenä että sosiaalista toimintana, jota siten säätelevät sekä kieliopin että sosiaalisen kanssakäymisen normit (Pietikäinen \& Mäntynen 2009: 13). Gee (1999: 6-7) erottaa nämä kaksi diskurssin merkitystä nimeämällä ensin mainitun Diskurssiksi isolla alkukirjaimella ja tarpeen mukaan monikollisena sanana (tiettyä maailmankuvaa heijastava kielenkäyttötapa) ja jälkimmäisen diskurssiksi pienellä alkukirjaimella käyttäen sitä aina yksikössä (ylipäätään kielenkäyttö kontekstissa). Vuori (2001) on puolestaan jakanut diskurssin

3 Kirjoittajien mielestä tulkintarepertuaari, joka "ei kanna samanlaisia rasitteita mukanaan kuin diskurssin käsite", soveltuu luontevimmin tutkimustehtäviin, joissa tarkastellaan yksityiskohtaisesti arkisen kielenkäytön vaihtelevuutta, siinä missä diskurssi on heidän mukaansa omimmillaan tarkasteltaessa ilmiöiden historiallisuutta, valtasuhteita ja institutionaalisia sosiaalisia käytäntöjä (Jokinen ym. 2016: 34-35). 
käsitteen merkitykset kolmeen: pienessä merkityksessään se viittaa lähinnä kielen ilmiöön, joka ulottuu lause- ja virkerajan yli. Keskisuuressa merkityksessään käsitettä käytetään, kun diskursseja tarkastellaan tietyssä tekstiaineistossa, suhteutetaan toisiinsa ja nimetään (esim. jalkapallodiskurssi, talousuutisten diskurssi). Laajimmillaan käsitettä käytettäessä yksittäiset lausumat ja tekstijaksot liitetään suuriin historiallisiin prosesseihin ja ajattelujärjestelmien muutoksiin.

Adamin (1999: 39) määritelmässä korostuu tekstin käsite: diskurssi on teksti kontekstissaan. Teksti tarkoittaa kielellistä merkityskokonaisuutta, jonka osat ovat sidoksissa toisiinsa ja jolla on jokin funktio (Halliday \& Hasan 1976: 1-2). Diskurssintutkijan aineistona ei siis ole satunnaiset kielenkäytön palaset vaan tekstit tai niiden osat: merkityskokonaisuudet, jotka on tuotettu jotain tarkoitusta varten. Toisinaan aineistona voi olla vaikkapa tiettyjen sanojen tai tietyn kielioppirakenteen esiintymät teksteissä, jolloin diskurssianalyyttiseksi tutkimuksen tekee se, että näitä esiintymiä analysoidaan osana tietynlaista tekstiä. Tekstiä analysoidessa otetaan huomioon relevantti taustatieto esimerkiksi osallistujien välisistä suhteista ja yhteiskunnallisesta tilanteesta (McCabe 2011; Spitzmüller \& Warnke 2011).

Hylandin (2005: 6) mukaan diskurssia tutkiessamme analysoimme niitä tapoja, joilla kielellisiä rakenteita käytetään sosiaalisten päämäärien saavuttamiseksi. Määritelmä on laaja ja kattaa hyvin monenlaiset diskurssintutkimuksen lähestymistavat. Jokinen (2016) tarkastelee diskurssianalyysiä suhteessa sukulaistraditioihin - retoriikkaan, keskustelunanalyysiin, semiotiikkaan ja etnografiaan - ja toteaa, että tutkimuskohteen valintaa sekä aineistotyyppejä ja analysointitapaa koskevista painotuseroista huolimatta "[k]äytännössä analyyttiset sovellukset ovat joskus niin lähellä toisiaan tai eri lähestymistapojen risteytyksiä, ettei yksittäisiä tutkimuksia voi välttämättä luokitella selkeästi yhden tradition edustajaksi" (mts. 263. Lähestymistapojen eroista, ks. taulukko s. 264).

Luukka (2000: 144-153) erottaa diskurssintutkimuksen piirissä neljä eri suuntausta: tekstuaalinen, kognitiivinen, interaktionaalinen ja konstruktiivinen. Tekstuaalisella suuntauksella Luukka (mts. 144-145) tarkoittaa diskurssin tarkastelua "lauseiden ja virkkeiden muodostamana itsenäisenä kokonaisuutena", jossa vallitsee hierarkia: tutkimus pyrkii selvittämään, millainen hierarkia tekstin eri osien välillä vallitsee. Kognitiivinen näkökulma diskurssintutkimuksessa puolestaan viittaa tekstin tuottamisen ja ymmärtämisen kognitiivisten prosessien tutkimiseen. Interaktionaalinen diskurssintutkimuksen suuntaus tarkoittaa vuorovaikutustilanteiden tarkastelua, ja sen perustana on ajatus siitä, että "merkitysten tulkinta ja ymmärtäminen perustuvat siihen, mitä vuorovaikutustilanteessa tapahtuu" (mts. 148). Konstruktionistinen näkökulma tarkoittaa kontekstin ymmärtämistä laajemmin kuin aiemmin mainituissa suuntauksissa: keskiössä on yhteisöt, joissa kieltä käytetään. Konstruktionistinen diskurssintutkimus perustuu sille ajatukselle, että kielenkäyttö on keskeinen osa yhteisöjen toimintaa ja kielenkäyttö myös rakentaa yhteisöjä (mts. 151-153). Luukan esittämä jaottelu on jo lähes 20 vuoden takaa, mutta se kuvastaa 
yhä osuvasti diskurssintutkimuksen moninaisuutta. Eri suuntauksien välille on kuitenkin viime vuosina rakentunut yhä enemmän siltoja ja yksittäisissä tutkimuksissa niitä voidaan yhdistellä monin tavoin.

Yhteistä kaikille neljälle suuntaukselle on se, että diskurssintutkijan tutkimuskohteena ovat tekstissä ja sitä ympäröivässä kielenkäyttötilanteessa esiin nousevat merkitykset. Kielenkäyttötilanne voidaan Pietikäisen ja Mäntysen (2009: 18) mukaan ymmärtää "pienimmillään yksittäisenä mikrotason vuorovaikutustapahtumana, kuten arkisena sananvaihtona tai muistilappuna, ja laajimmillaan kokonaisena yhteiskunnallisena ja historiallisena makrotason tilanteena" sekä kaikkena tältä väliltä. Lisäksi nykytutkimuksessa pyritään usein luopumaan "mikron" ja "makron" käsitteistä ja niihin liittyvistä menetelmällisistä siirtymistä (ks. esim. Pietikäinen 2012).

Kysymys kielenkäyttötilanteen eli kontekstin piirteiden huomioimisesta on keskeinen diskurssintutkimuksessa: miten tarkasti ja millä tasoilla tekstistä nousevia merkityksiä analysoidaan suhteessa kontekstiin? Faircloughin esittämä kolmitasoinen malli tekstuaalisen tason, diskursiivisen tason ja sosiaalisen tason huomioimisesta on yleisesti tunnettu (ks. esim. Fairclough 1997: 82). Nykypäivänä diskurssintutkimus laajenee yhtäältä suurten aineistojen suuntaan (esim. Jantunen tässä teemanumerossa), jolloin painopiste on tekstuaalisen ja laajemman sosiaalisen tason analyysissä, toisaalta kielenkäyttötilanteen (multimodaaliseen) mikrotason analyysiin (esim. Stevanovic ja Weiste tässä teemanumerossa), jolloin painopiste on tekstuaalisella ja välittömällä sosiaalisella tasolla, tai tekstin tuotannon institutionaaliseen kontekstiin (esim. Haapanen tässä teemanumerossa), jolloin painopiste on toiminnan analyysissä.

\section{Menetelmiä tutkimuksen eri vaiheissa}

Tämä teemanumero pureutuu diskurssintutkimuksen menetelmiin. Kuten edellä totesimme, diskurssintutkimus tai -analyysi ei ole valmis menetelmä, jolla voisi ratkoa erilaisia tutkimuskysymyksiä ja jota voisi soveltaa eri aineistoihin, vaan diskurssintutkimuksessa hyödynnetään monia valmiita menetelmiä sekä operationalisoidaan teorioita ja käsitteitä menetelmiksi. Tieteenteoreettisesti katsottuna menetelmä tarkoittaa usein samaa kuin metodi, ja nämä molemmat termit viittaavat siihen, miten tutkimus toteutetaan. Esimerkiksi Luodonpää-Mannin (2013) tieteenteoreettisia termejä käsittelevässä kyselytutkimuksessa kielentutkijoille metodi ja menetelmä ovat käytännössä synonyymeja ja termien merkityksestä vallitsee vastaajien keskuudessa lähes yksimielisyys: ne viittaavat konkreettiseen keinoon tai instrumenttiin jonkun ilmiön tutkimisessa (Luodonpää-Manni 2013: 253). Luodonpää-Mannin kyselytutkimuksessa vastaajina oli tutkijoita kielitieteen eri osa-alueilta; joukkoon mahtui varmasti diskurssintutkijoita, mutta myös monet muut kielentutkimuksen alat olivat edustettuina. Vastaajat näkivät teorian olevan kiinteässä yhteydessä menetelmään: 
teoria on todellisuutta koskeva kuvaus, jonka tutkimiseen menetelmä tarjoaa välineet (mts. 254). Jotkut teoriat toimivat kuitenkin myös menetelminä: esimerkiksi keskustelunanalyysi nähdään usein paitsi menetelmänä, myös teoriana vuorovaikutuksesta (ks. Etelämäki ym. 2009; Pikkarainen 2010).

Luodonpää-Mannin (2017) tutkimus tieteenteoreettisten termien käytöstä suomenkielisissä kielitieteen tutkimusartikkeleissa puolestaan osoittaa, että käsitteitä metodi ja menetelmä käytetään erilaisissa merkityksissä. Erityisesti esiin nousee metodin/menetelmän merkitys aineiston analyysitavan lisäksi aineistonkeruun tapana. Niiniluoto (1980: 28) puolestaan käyttää metodin/menetelmän sijaan termiä metodiikka ja luettelee sen neljä osa-aluetta: aineiston keräämisen, kuvaamisen ja analyysin sekä johtopäätösten tekemisen tekniikat. Tässä teemanumerossa diskurssintutkimuksen menetelmiä tarkastellaan monista näkökulmista. Toisin sanoen ymmärrämme menetelmänä tavan, jolla voidaan kuvata tutkimuksen teon eri vaiheita. Joissain artikkeleissa korostuu aineiston keruun, tallentamisen ja luokittelun tapa, joissain puolestaan aineiston analyysitapa. Nämä vaiheet ovat vuorovaikutuksessa keskenään: yhden vaiheen suhteen tehdyt valinnat mahdollistavat, rajoittavat tai edellyttävät tietynlaisia valintoja toisessa vaiheessa, missä tehdyt valinnat puolestaan heijastuvat takaisin toisiin vaiheisiin. Tutkimusasetelman rakentaminen on siis luonteeltaan iteratiivinen prosessi, jonka kuluessa tehdyt valinnat vaikuttavat ratkaisevasti siihen, miten selitysvoimaisia ja luotettavia tuloksia tutkimus tuottaa.

Tämän teemanumeron artikkelit kuvaavat kukin jotakin diskurssintutkimuksen menetelmää jossain tutkimuksenteon vaiheessa. Tarkastelemme seuraavassa artikkeleittain sitä, tarkastelevatko ne menetelmiä aineiston keräämisen ja/tai sen analyysin välineenä ja minkälaiset asiat kussakin tutkimusasetelmassa ovat menetelmän valinnan ja tilanteisen soveltamisen kannalta keskeisiä.

Tutkimusaineiston hankinnan lähtökohtana ovat usein tutkimusongelmat tai -tehtävät, jotka sitten ohjaavat aineiston keruuta. Vaihtoehtoisesti voidaan edetä päinvastaisessa järjestyksessä eli etsiä jo olemassa olevaan aineistoon uusi näkökulma ja tutkimusongelma. Varsinkin tilanteessa, jossa aineiston kerääminen on vaatinut suuria henkilö-, aika- ja/tai infrastruktuuriresursseja, on taloudellista ja tutkimusalaa eteenpäin vievää, että samaa aineistoa voidaan hyödyntää useita kertoja.

Yksi tämän hetken keskeisimpiä teemoja niin diskurssintutkimuksessa kuin muussakin kielentutkimuksessa on teknologinen kehitys ja sen luomat uudet menetelmälliset mahdollisuudet. Yhtäältä teknologia mahdollistaa suurten aineistojen keräämisen ja analysoimisen uusin tavoin (ks. Jantunen tässä teemanumerossa). Toisaalta se, että kirjallinen ja multimodaalinen digitaalinen viestintä on yhä keskeisempi osa niin arkea kuin työelämää, mahdollistaa esimerkiksi kielenkäytön prosessien uudenlaisen jäljittämisen (ks. Haapanen tässä teemanumerossa) sekä erilaisten aineistotyyppien kuten äänen ja liikkuvan kuvan yhdistämisen esineisiin ja kenttämuistiinpanoihin (ks. Kuure ym. tässä teemanumerossa). 
Tässä teemanumerossa teknologiset apuvälineet aineiston keruussa ja käsittelyssä ovat aiheena erityisesti Jarmo H. Jantusen artikkelissa, jossa keskeistä on aineiston keruu ja luokittelu koneellisin menetelmin. Artikkelin aiheena on korpusavusteinen diskurssintutkimus (corpus-assisted discourse studies, CADS), joka yhdistää kaksi tutkimusperinnettä: kvantitatiivisen korpustutkimuksen ja laadullisen diskurssintutkimuksen. Jantunen kuvaa korpustutkimuksen ja diskurssintutkimuksen eroja ja yhtäläisyyksiä. Erot liittyvät erityisesti aineiston luonteeseen, kontekstin tärkeyteen, mikro- ja makrotason huomioimiseen sekä tulosten yleistettävyyteen. Jantunen kuitenkin korostaa sekä diskurssintutkimuksen että korpustutkimuksen moninaisuutta ja löytää myös monia yhtymäkohtia tutkimussuuntausten välille. Tärkeimmät yhtymäkohdat ovat todellisten kieliaineistojen käyttö ja nojautuminen toistuvuuteen.

CADS-tutkimuksessa aineisto voi olla valmiiksi kerätty, tai tutkimusta varten voidaan kerätä uusi aineisto. Koska avainasemassa on aineiston laajuus, aineisto kerätään aina koneellisin menetelmin. Tutkimuksessa voidaan myös tehdä uusia yhdistelmiä olemassa olevista aineistoista. Analyysin kohteeksi valikoidaan tutkimuskysymyksen kannalta relevantteja kielen yksiköitä, esimerkiksi sanoja. Tekstiä huomattavasti pienempien yksiköiden analyysi pohjautuu fraseologiseen näkemykseen eli siihen, että kieltä tuotetaan "muistiin varastoituneiden ja kielenkäyttäjien jakamien monisanasten yksiköiden sekä leksikaalis-kieliopillisten ja leksikaalis-semanttisten assosiaatioiden avulla" sen sijaan, että poimittaisiin muistista yksittäisiä kielellisiä elementtejä. CADS-tutkimuksessa aineistoa luokitellaan ja analysoidaan esimerkiksi kollokaatioiden, klustereiden ( $n$-grammien) tai semanttisten preferenssien ja diskurssiprosodioiden avulla. CADS-tutkimuksen analyysimenetelmien ytimessä on yhtäältä koneellinen analyysi, koska laajojen tekstimassojen luokittelu ja analyysi ei onnistuisi ilman koneellisia ja tilastollisia menetelmiä. Toisaalta keskeistä on myös laadullinen aineistossa ja sen luokitteluissa havaittavien diskurssien analyysi. Artikkelissaan Jantunen havainnollistaa CADSia tutkimuksella, jossa selvitetään seksuaalivähemmistöihin liittyviä diskursseja verkkokeskusteluissa.

Lauri Haapasen artikkeli lähestyy diskurssintutkimuksen menetelmiä erityisesti aineiston keräämisen ja käsittelyn näkökulmasta. Artikkeli tarkastelee kirjoittamisen ja tekstin tuottamisen tutkimusta, jota on perinteisesti tehty valmiita tekstejä analysoimalla (Grésillon \& Perrin 2014). Koska valmis teksti pyrkii parhaansa mukaan kätkemään kirjoitusprosessin jäljet, tekstiprodukteista koostuvan aineiston pohjalta on tehtävissä vain epäsuoria ja -luotettavia päätelmiä siitä, miten tekstin syntyprosessi on edennyt: onko teksti esimerkiksi kirjoitettu alusta loppuun edeten vai kenties kasvavaa tekstimassaa järjestellen ja sanavalintoja hioen? Vielä vaikeampaa valmiista tekstistä on päätellä kirjoittajan intentioita: miksi teksti kokonaisuutena ja yksityiskohdiltaan on juuri sellainen kuin se on?

Artikkelissaan Haapanen esittelee tutkimuskirjallisuuden pohjalta menetelmiä, jotka dokumentoivat tekstin syntymistä ja paljastavat seikkoja ja päämääriä, 
jotka tähän prosessiin ovat vaikuttaneet. Toisin sanoen kirjoittamista tarkastellaan sekä materiaalisena että mentaalisena toimintana, jota ohjaavat ja johon vaikuttavat erilaiset sosiaaliset päämäärät sekä kirjoitusprosessin välitön ko- ja konteksti (mikrotaso) ja ympäristö (mesotaso) sekä prosesseihin vaikuttavat institutionaaliset, yhteiskunnalliset ja/tai kulttuuriset tekijät (makrotaso). Artikkeli havainnollistaa näitä moniulotteisia aineistonkeruun menetelmiä journalistista siteerausta käsittelevän tutkimuksen avulla (Haapanen 2017). Päätelmänään artikkeli esittelee viisi menetelmällistä suositusta, jotka voivat auttaa kirjoittamisen ja tekstin tuottamisen kokonaisvaltaisessa tutkimuksessa. Suositukset on laadittu erityisesti ammattimaisen kirjoittamisen tutkimuksen pohjalta, mutta ne ovat hyödynnettävissä myös muunlaisessa luku- ja kirjoitustaidon (literacy) tutkimuksessa.

Leena Kuuren, Maritta Riekin ja Riikka Tumeliuksen artikkeli esittelee neksusanalyysiksi kutsutun lähestymistavan, joka pohjautuu välitteiseen näkemykseen sosiaalisesta toiminnasta ja vuorovaikutuksesta. Toisin sanoen näkemys pyrkii yhdistämään erilaisia tulkinnan tasoja ja tarkastelemaan niitä sekä paikallisten vuorovaikutustekijöiden että kulttuuristen ja institutionaalisten diskurssien ja rakenteiden risteymänä. Diskurssintutkimuksessa tämä edellyttää sitä, että kieltä ei nähdä vain tilanteisena kommunikaationa, jota aineistonkeruussa tallennetaan ja edelleen analysoidaan, vaan sosiosemioottisen merkitysneuvottelun kokonaisuutena, joka tapahtuu tässä ja nyt mutta joka samalla ulottuu ajallisesti ja paikallisesti kauemmaksi. Tässä artikkelissa luodaan katsaus neksusanalyysiä ja välitteistä diskurssinanalyysiä hyödyntävään tutkimukseen kielenoppimisen, kielipedagogiikan ja kieltenopettajakoulutuksen aloilla. Vaikka tutkimus alalla on vielä nuorta ja muovautumassa ja teoreettis-menetelmällisiä lähtökohtia tulkitaan monella tavalla, neksusanalyysi on osoittautunut hedelmälliseksi lähestymistavaksi tämänkaltaisten kompleksisten ilmiöiden tutkimisessa.

Aineiston analyysimenetelmän tai -menetelmien valintaan vaikuttaa luonnollisesti se, minkälaisiin tutkimuskysymyksiin tutkimuksella ollaan vastaamassa. Analyysimenetelmien perusjakona pidetään yleensä jakoa määrälliseen ja laadulliseen analyysiin, mutta näiden yhdistäminen on yhä yleisempää ( $k$ s. Jantunen tässä teemanumerossa). Diskurssianalyyttistä menetelmää voidaan esimerkiksi soveltaa aineistoon, jotta saadaan vaikkapa sosiaalitieteiden kysymyksiä ratkottaessa syvällinen ymmärrys viestintätilanteessa rakentuvista merkityksistä (ks. Niska ym. ja Stevanovic \& Weiste tässä teemanumerossa). Diskurssintutkimuksen menetelmiä myös yhdistellään yhä enemmän. Etenkin digitaalisten viestien tutkiminen vaatii usein uudenlaisia menetelmällisiä lähestymistapoja, kun viestinnän luonne on muuttunut (ks. Virtanen \& Kääntä tässä teemanumerossa). Viestinnän digitaalinen murros haastaa toisaalta myös kokeilemaan, voidaanko perinteisillä menetelmillä kuvata ihmisten välistä viestintää, kun se tapahtuu digitaalisten viestintäkanavien välityksellä (ks. Lehti ja Eronen-Valli tässä teemanumerossa). 
Miira Niskan, Antero Olakiven ja Kari Mikko Vesalan artikkelissa kuvataan, miten diskurssianalyyttinen menetelmä on sovellettavissa aineistoon, johon sen ei ole aina nähty sopivan. Kyseessä on haastatteluaineiston diskurssianalyyttinen tarkastelu sosiaalitieteellisessä tutkimuksessa, joka kohdistuu ihmisten asenteisiin. Perinteisesti haastatteluaineistoa on sosiaalitieteissä analysoitu siitä näkökulmasta, että haastattelupuhe koostuu faktoista, jotka kuvaavat todellisuutta - esimerkiksi haastateltavan omia asenteita - sellaisenaan. Haastattelutilanne ja siinä tapahtuva vuorovaikutus on nähty "metodisena hienosäätönä", jonka mahdollinen vaikutus haastattelupuheeseen on vain mainittu. Artikkelissa vedetään yhteen sosiaalitieteissä parin viime vuosikymmenen ajan käytyä keskustelua haastatteluaineistojen käytöstä niin haastattelun toteutuksen kuin haastattelupuheen analyysinkin osalta. Edellä mainittu, essentialistis-realistiseksi nimetty tapa nähdä haastattelupuhe faktoina on saanut rinnalleen relationistis-konstruktionistisen tulkinnan, jonka ydinajatus on, että haastattelu viestintätilanteena muokkaa vahvasti sitä, mitä haastateltava sanoo ja miten hän puhuu. Relationistis-konstruktiivisessa lähestymistavassa haastattelun ei nähdä olevan vain tietojen keräämistapa, vaan haastatteluvuorovaikutus itsessään nousee tutkimuskohteeksi. Artikkelin kirjoittajat arvioivat molempien menetelmien etuja ja ongelmia.

Niskan, Olakiven ja Vesalan artikkelin empiirinen osa kuvaa Helsingin yliopiston sosiaalitieteiden laitoksella kehitettyä laadullista asennetutkimusta, jonka aineisto kerätään puolistrukturoiduilla haastatteluilla, joissa haastateltavaa ohjataan kertomaan vapaasti asenteistaan erilaisten virikkeiden, kuten väitteiden, kysymysten tai valokuvien avulla. Näin muodostuu tutkimusaineisto, virikkeestä käytävä keskustelu, joka litteroidaan. Analyysivaiheessa aineistoa tulkitaan puhetekoina ja vuorovaikutteisena toimintana, jossa haastattelijan osuutta ei pyritä häivyttämään. Analyysi koostuu luokittavasta ja tulkitsevasta vaiheesta. Luokittavassa vaiheessa tunnistetaan ja ryhmitellään haastattelupuheessa esiintyvät kannanotot ja perustelut. Tulkitseva vaihe on erityisen keskeinen diskurssintutkimuksen näkökulmasta. Tässä analyysin vaiheessa ei niinkään tarkastella sitä, mitä sanotaan, vaan relationistis-konstruktionistisen näkökulman mukaisesti sitä, miten sanotaan.

Melisa Stevanovicin ja Elina Weisteen artikkeli fokusryhmätutkimuksen keskustelunanalyyttisesta soveltamisesta lähtee liikkeelle menetelmän mahdollisuuksista analyysivaiheessa. Stevanovic ja Weiste argumentoivat artikkelissaan sen puolesta, että fokusryhmätutkimukselle tyypillinen diskursiivinen ote ja analyysi sisältö- ja teemalähtöisesti kaipaa rinnalleen fokusryhmän vuorovaikutuksen mikrotason tarkastelua eli keskustelunanalyyttista puheenvuorojen ja toimintojen rakentumisen tarkastelua. Tällaisella kahden menetelmän yhdistämisellä voidaan kirjoittajien mukaan päästä kiinni niihin sosiaalisiin käytäntöihin ja toimintoihin, jotka vaikuttavat ja vallitsevat fokusryhmän toiminnan ulkopuolella mutta jotka osaltaan selittävät fokusryhmän puheen sisältöjä. Näiden kahden menetelmän lisäksi kirjoit- 
tajat havainnollistavat esimerkein, kuinka erilaisilla virikemateriaaleilla fokusryhmätutkimus saa uuden ulottuvuuden.

Stevanovicin ja Weisteen artikkeli keskittyy ensin luotaamaan fokusryhmien diskursiivista tutkimusta ( $\mathrm{mm}$. kategoria-analyysi, diskursiivinen psykologia) ja merkitysten tärkeyttä sosiaalisen toiminnan muodostamisessa, minkä jälkeen osoitetaan keskustelunanalyyttisten toimintojen ja toimintajaksojen rooli merkitysten tulkinnan rinnalla. Artikkelin kysymykset on jaettu kahteen osaan: ensimmäisessä tarkastellaan fokusryhmän vuorovaikutuksen dynamiikkaan liittyviä aiheita (keskustelunanalyysi ja siitä "lainatut" käsitteet) ja toisessa puolestaan fokusryhmän vuorovaikutuksen sosiaaliseen todellisuuteen ja tilanteen ulkopuoliseen maailmaan liittyviä, kulttuurisia merkityksiä (fokusryhmien diskursiivinen tutkimus ja siitä "lainatut" käsitteet). Kysymyksiä peilataan kirjoittajien aikaisempien tutkimusten fokusryhmäaineistoihin. Artikkelin lopussa pohditaan menetelmien yhdistämisen toimivuutta, sen hyötyjä ja haasteita. Kirjoittajat näkivät haasteena erityisesti sen, kuinka saada pysymään tutkimuskohteena oleva ilmiö niin fokusoituna, ettei vuorovaikutustilanteiden monipuolisuus ja yksityiskohtaisuus "tyrmää" tutkijaa. Hyötynä kirjoittajat osoittivat sen, että menetelmien yhdistämisellä saadaan aikaan tervettä vuoropuhelua, jolla edistetään tutkimusta ja tulkintaa sosiaalisen todellisuuden luonteesta ja ylläpitämisestä.

Mikko Virtasen ja Liisa Käännän artikkeli keskittyy niinikään kuvaamaan menetelmän mahdollisuuksia analyysivaiheessa. Artikkelin keskiössä on kahden menetelmän yhdistäminen, ja tavoitteena on osoittaa, että yhdistelmämenetelmä selittää tutkimuskohdetta monipuolisemmin ja ansiokkaammin kuin kumpikaan menetelmä yksinään. Artikkelissa yhdistetään kirjoitetun vuorovaikutuksen tutkimuksen lähestymistapoja soveltavaan, erityisesti digitaaliseen keskustelunanalyysiin. Kirjoitetun vuorovaikutuksen tutkimus on kattotermi, johon on artikkelissa sisällytetty muun muassa retorisen rakenteen teoriaa, suhtautumisen teoriaa ja kirjoittamisen sosiaalis-vuorovaikutteista tutkimusta, jotka näkyvät esimerkiksi genren käsitteen hyödyntämisessä sekä evaluoivien ilmausten analyysissa. Digitaalisen keskustelunanalyysin puitteissa artikkelissa on hyödynnetty sekventiaalisuuden, progressiivisuuden ja moniosaisen vuoron käsitteitä sen suhteen, miten ne rakentuvat digitaalisessa aineistossa. Keskeistä on se, että molempia menetelmällisiä lähestymistapoja yhdistää laadullinen, mikrotason valintojen analyysi, jolla osoitetaan ja todistetaan kulloisenkin diskurssin vuorovaikutuksellinen järjestyneisyys.

Kirjoittajat tarkastelevat yhdistelmämenetelmällä nimenomaan kirjoitetun vuorovaikutuksen monipuolista rakentumista, mikä näkyy aineiston valinnassa. Empiiriseksi osioksi valikoitui asynkronista viestintää edustava Lukupiiri-blogi ja sieltä yksi blogikirjoitus kommentteineen. Aineiston analyysi on kaksiosainen: ensimmäisessä osiossa paneudutaan blogikirjoituksen rakentumiseen yhtäältä genrepiirteiden valintoina ja toisaalta yleisöön suuntautuvana tekstinä, joka mahdollistaa vuorovaikutteisuuden kirjoittajan ja yleisön - tässä tapauksessa lukijoiden ja kom- 
mentoijien - välillä. Toisessa osiossa analysoidaan blogikirjoituksen kommentteja siitä näkökulmasta, minkälaisia vuoroja ne ovat ja miten niissä osoitetaan yhteyttä blogikirjoitukseen. Näissä kahdessa analyysi- ja tulosluvussa on nähtävissä myös se, miten menetelmät täydentävät toisiaan. Menetelmien yhdistämisellä osoitettiin se, että asynkronisessa verkkoviestinnässä vuorovaikutus rakentuu sekä eksplisiittisistä että implisiittisistä valinnoista, joilla ilmennetään, toistetaan, ylläpidetään, reagoidaan muiden tekemiin valintoihin, ja tällä kaikella puolestaan tuotetaan topikaalista ja toiminnallista jatkuvuutta ensinäkemältä irralliselta vaikuttavaan tekstien joukkoon. Menetelmistä "lainatut" käsitteet mahdollistivat mikrotason valintojen tarkastelun, minkä perusteella yhdestä blogikirjoituksesta kommentteineen pystyttiin antamaan kaksi limittyvää näkemystä: blogikirjoitus yleisöön suuntautuvana, argumentoivaa genretyyppiä ilmentävänä tekstinä ja kirjoituksen kommentit argumentointia eri tavoin jatkavana keskusteluna.

Myös Lotta Lehden ja Maria Eronen-Vallin artikkelissa tarkastellaan aineiston analyysivaiheen menetelmiä. Artikkelissa esitellään diskurssianalyysille ominaisten menetelmien käyttöä digitaalisen retoriikan tutkimuksessa. Digitaalinen retoriikka on Pohjois-Amerikasta lähtöisin oleva uudehko tutkimussuuntaus, joka tutkii viestinnällistä vaikuttamista digitaalisissa ympäristöissä. Digitaalinen retoriikka on vahvasti monitieteinen tutkimussuuntaus, joka hyödyntää menetelmiä esimerkiksi kielentutkimuksen, viestintätieteiden, kulttuurintutkimuksen, sosiologian ja informaatioteknologian aloilta. Lehti ja Eronen-Valli keskittyvät kuitenkin nimenomaan diskurssianalyyttisten menetelmien kuvaamiseen.

Digitaalisen retoriikan tutkimuksessa tutkimuskohde on vaikuttamisen keinot digitaalisessa viestinnässä. Näin ollen aineistot koostuvat pääosin digitaalisista teksteistä, jotka voivat olla hyvinkin multimodaalisia. Tekstien analyysiä voidaan digitaalisessa retoriikassa täydentää esimerkiksi haastatteluilla tai käyttäjäanalytiikalla. Lehti ja Eronen-Valli keskittyvät kuitenkin sellaisiin tutkimuksiin, joissa aineistona on yksinomaan digitaalisia tekstejä. Esitellyt tutkimukset ovat pääosin aineistolähtöisiä: tutkimuksen lähtökohtana on ollut tietty digitaalinen viestintämuoto (esim. Wikipedia, poliitikon blogi tai sanomalehden kommenttiosio) ja tästä on edetty aineiston valintaan ja rajaukseen sekä tutkimuskysymysten muodostamiseen. Diskurssianalyyttisesti orientoituneessa digitaalisen retoriikan tutkimuksessa menetelmä siis viittaa ennen kaikkea tapaan, jolla tutkittavaa teoriaa tai käsitettä tutkitaan aineistosta, toisin sanoen analyysimenetelmään. Kuvatuissa tutkimuksissa analyysi kohdistuu esimerkiksi kirjoittajan eetokseen eli puhujakuvaan, jota tutkitaan muun muassa subjektiivisuuden ja asennoitumisen ilmausten kautta sekä argumentointiin eli väitteiden perustelemiseen. Mukana on myös esimerkki tutkimuksesta, jossa rakennetaan klassisen retoriikan käsitteestä (entymeema) uusi, digitaaliseen ympäristöön paremmin soveltuva käsite (digitaalinen entymeema). 


\section{$4 \quad$ Lopuksi}

Tämä teemanumero kokoaa yhteen erilaisia näkökulmia diskurssintutkimuksen menetelmiin: miten diskurssia ja diskursseja käsitetään, minkälaisia tutkimuskohteita ne mahdollistavat, minkälaisia tutkimusasetelmia niiden ympärille rakennetaan ja miten ja minkälaisia aineistoja niiden tutkimista varten kerätään ja analysoidaan. Nykytilanteen kuvaamisen ohella teemanumeron artikkelit osoittavat myös suuntaa diskurssintutkimuksen tulevaisuudelle. Tästä kertoo erityisesti artikkeleissa ilmenevä käsitteiden runsaus ja niiden kokeileva käyttö.

Artikkeleiden perusteella diskurssintutkimus näyttää yhä enemmän teoreettis-menetelmälliseltä lähestymistavalta, joka lainaa toisista menetelmistä, tieteenaloista ja teorioista "osia" - se on siis moni- ja poikkitieteellistä ja siten nykyisen tieteenteon ytimessä. On syytä olettaa, että tulevaisuudessa diskurssintutkimus on entistä enemmän miksi-kysymykseen keskittyvää, syvemmälle tekstiin ja sen tuottamisen yksityiskohtiin porautuvaa ja/tai toisaalta suuriakin datamassoja hyödyntävää kokeilevaa tutkimusta, jota ei voi pelkistää yksittäisten puhetapojen tai merkitysten tutkimukseksi. On myös todennäköistä, että esimerkiksi etnografista tutkimusotetta hyödynnetään diskurssintutkimuksessa vielä nykyistäkin monipuolisemmin. Tältä pohjalta on oletettavaa, että analyysivaiheen menetelmien sijaan myös aineistonkeruun menetelmien rooli tutkimusprosessissa tulee kasvamaan.

Diskurssintutkimuksen tulevaisuuden näyttäessä yhä monitieteisemmältä ja -menetelmäisemmältä on erityisen tärkeää, että kussakin yksittäisessä tutkimuksissa kuvataan tutkimusprosessi riittävän läpinäkyvästi. Näin tutkimuksen luotettavuus on riittävällä tavalla arvioitavissa. On myös tarpeellista asemoida itsensä ja tutkimuksensa selkeästi suhteessa diskurssintutkimuksen moniin haaroihin. Toivomme, että tämä teemanumero helpottaa tulevien tutkimusten eri vaiheissa käytettyjen menetelmien valintaa, kuvausta ja arviointia.

\section{Kirjallisuus}

Adam, J.-M. 1999. Linguistique textuelle. Des genres de discours aux textes. Paris: Nathan. Alba-Juez, L. 2009. Perspectives on discourse analysis: theory and practice. Cambridge: Cambridge Scholar Publishing.

Angermuller, J., D. Maingueneau \& R. Wodak 2014. The discourse studies reader: an introduction. Teoksessa J. Angermuller, D. Maingueneau \& R. Wodak (toim.) The discourse studies reader. Amsterdam: John Benjamins, 1-14.

Blommaert, J. 2005. Discourse - A critical introduction. Cambridge: Cambridge University Press.

Brown, G. \& G. Yule 1983. Discourse analysis. Cambridge: Cambridge University Press.

Etelämäki, M., I. Herlin, M. Jaakola \& L. Visapää 2009. Kielioppi käsitteistyksenä ja toimintana. Kognitiivista kielioppia ja keskustelunanalyysiä yhdistämässä. Virittäjä, 113 (2), 162-187. https://journal.fi/virittaja/article/view/4182. 
Fairclough, N. 2003. Analysing discourse: textual analysis for social research. London: Routledge.

Fairclough, N. 1997. Miten media puhuu. Alkuperäisteoksen Media discourse suomentanut V. Blom ja K. Hazard. Tampere: Vastapaino.

Gee, J. 1999. Introduction to discourse analysis: theory and method. London: Routledge.

Grésillon, A. \& D. Perrin 2014. Methodology: from speaking about writing to tracking text production. Teoksessa E.-M. Jakobs \& D. Perrin (toim.) Handbook of writing and text production. Berlin: De Gruyter Mouton, 79-111.

Gunther, K. \& T. van Leeuwen. 2001. Multimodal discourse: the modes and media of contemporary communication. London: Arnold.

Haapanen, L. 2007. Quoting practices in written journalism. Helsinki: Helsingin yliopisto. https://helda.helsinki.fi/handle/10138/174618.

Halliday, M. A. K. \& R. Hasan 1976. Cohesion in English. London: Longman.

Hyland, K. 2005. Metadiscourse. London: Continuum.

ledema, R. 2003. Multimodality, resemiotization: extending the analysis of discourse as multi-semiotic practice. Visual Communication, 2 (1), 29-57. https://doi.org/10.1177/1 470357203002001751.

Itkonen, E. \& A. Pajunen 2010. Empiirisen kielitieteen metodologia (Suomi 199). Helsinki: Suomalaisen Kirjallisuuden Seura.

Jokinen, A. 2016. Diskurssianalyysin suhde sukulaistraditioihin. Teoksessa A. Jokinen, K. Juhila \& E. Suoninen (toim.) Diskurssianalyysi - teoriat, peruskäsitteet ja käyttö. Tampere: Vastapaino, 249-265.

Jokinen, A., K. Juhila \& E. Suoninen 2016. Diskurssianalyysi - teoriat, peruskäsitteet ja käyttö. Tampere: Vastapaino.

Kolehmainen, L., M. Miestamo \& T. Nordlund (toim.) 2013. Kielten vertailun metodiikka (SKS:n toimituksia 1387). Helsinki: Suomalaisen Kirjallisuuden Seura.

Konstenius, R. 2014. Empiria, eksperimentti ja etiikka. Kielitieteen metateoriaa. Helsinki: Helsingin yliopisto. 127-147. Helsinki: Suomalaisen Kirjallisuuden Seura.

Krzyżanowski, M. 2011. Ethnography and critical discourse analysis: towards a problemoriented research dialogue. Critical discourse studies, 8 (4), 231-238. https://doi.org/10. 1080/17405904.2011.601630.

Luodonpää-Manni, M. 2013. Kyselytutkimus kielentutkijoiden yleistieteellisille termeille antamista merkityksistä. Virittäjä, 117 (2), 242-264. https://journal.fi/virittaja/article/ view/8314.

Luodonpää-Manni, M. 2017. The choice between generic scientific terms in linguistic research articles. Teoksessa M. Luodonpää-Manni, E. Penttilä \& J. Viimaranta (toim.) Empirical approaches to cognitive linguistics: analyzing real-life data. Newcastle Upon Tyne: Cambridge Scholars Publishing. 177-214.

Luodonpää-Manni, M., M. Hamunen, R. Konstenius, M. Miestamo, U. Nikanne \& K. Sinnemäki (toim.) tulossa. Kielentutkimuksen metodologian käsikirja.

Luukka, M.-R. 2000. Näkökulma luo kohteen: diskurssintutkimuksen taustaoletukset. Teoksessa K. Sajavaara, A. Piirainen-Marsh (toim.) Kieli, diskurssi \& yhteisö. Jyväskylä: Soveltavan kielentutkimuksen keskus, 133-160.

Martin, J. R. \& P. R. R. White. 2005. The language of evaluation. Appraisal in English. New York, NY: Palgrave Macmillan.

Machin, D. 2013. What is multimodal critical discourse studies? Critical Discourse Studies, 10 (4), 347-355. https://doi.org/10.1080/17405904.2013.813770.

McCabe, A. 2011. An introduction to linguistics and language studies. London: Equinox. 
Mikkonen, I. 2010. "Olen sitä mieltä, että...." Lukiolaisten yleisönosastotekstien rakenne ja argumentointi. Jyväskylä studies in humanities 135. Jyväskylä: Jyväskylän yliopisto. https://jyx.jyu.fi/handle/123456789/23021.

Miller, C. R. 1984. Genre as social action. Quarterly Journal of Speech, 70. 151-167.

Niglas, K. 2004. The combined use of qualitative and quantitative methods in educational research. Põltsamaa: Vali Press.

Niiniluoto, I. 1980. Johdatus tieteenfilosofiaan. Helsinki: Otava.

Parker, I. 1992. Discourse dynamics: critical analysis for social and individual psychology. London: Routledge.

Pietikäinen, S. \& A. Mäntynen 2009. Kurssi kohti diskurssia. Tampere: Vastapaino.

Pikkarainen, M. 2010. TV-toimittajan kolmannen position vuoroista Venäjän televisiossa. Dialogipartikkelit ja interventiot. Puhe ja kieli, 30 (2), 107-120. https://journal.fi/pk/ article/view/4733.

Porttikivi, M. 2016. Organisaatioiden diskursiivinen legitimaatio kiistelevässä verkkojulkisuudessa. Helsinki: Aalto-yliopisto.

Perrin, D. 2003. Progression analysis (PA): investigating writing strategies at the workplace. Journal of Pragmatics 35 (6), 907-921. https://doi.org/10.1016/S03782166(02)00125-X.

Pietikäinen, S. 2012. Kieli-ideologiat arjessa: neksusanalyysi monikielisen inarinsaamenpuhujan kielielämäkerrasta. Virittäjä, 116 (3), 410-442. https://journal.fi/ virittaja/article/view/7162.

Pynnönen, A. 2013. Diskurssianalyysi: tapa tutkia, tulkita ja olla kriittinen. Jyväskylän yliopiston kauppakorkeakoulun Working Paper N:o 379. Jyväskylä: Jyväskylän yliopisto. Saatavilla: https://jyx.jyu.fi/bitstream/handle/123456789/42412/978-951-39-5471-0. pdf?sequence.

Renkema, J. 2004. Introduction to discourse studies. Amsterdam: John Benjamins.

Reyes, A. 2011. Strategies of legitimization in political discourse: from words to actions. Discourse and Society, 22 (6), 781-807. https://doi.org/10.1177/0957926511419927.

Spitzmüller, J. \& I. Warnke 2011. Discourse as a "linguistic object": methodical and methodological delimitations. Critical Discourse Studies, 8 (2), 75-94. https://doi.org/1 0.1080/17405904.2011.558680.

Schiffrin D., D. Tannen \& H. E. Hamilton (toim.) 2003. The Handbook of discourse analysis. Oxford: Blackwell.

Stevanovic, M. \& C. Lindholm (toim.) 2016. Keskustelunanalyysi. Kuinka tutkia sosiaalista toimintaa ja vuorovaikutusta. Tampere: Vastapaino.

Virsu, V. 2012. Sitouttamisretoriikka yritysviestinnässä. Turku: Turun yliopisto. https://www. utupub.fi/handle/10024/73970.

Vuori, J. 2001. Äidit, isät ja ammattilaiset. Sukupuoli, toisto ja muunnelmat asiantuntijoiden kirjoituksissa. Tampere: Tampere University Press.

Wetherell, M., S. Taylor \& S. J. Yates 2001. Introduction. Teoksessa M. Wetherell, S. Taylor \& S. J. Yates (toim.) Discourse as data. A guide for analysis. London: The Open University \& Sage Publications Ltd, i-iv.

Wodak, R. \& M. Meyer (toim.) 2011. Methods of critical discourse analysis. London: Sage. 